IRA-International Journal of Management \& Social Sciences

ISSN 2455-2267; Vol.06, Issue 01 (2017)

Pg. no. 97-103

Institute of Research Advances

http://research-advances.org/index.php/RAJMSS

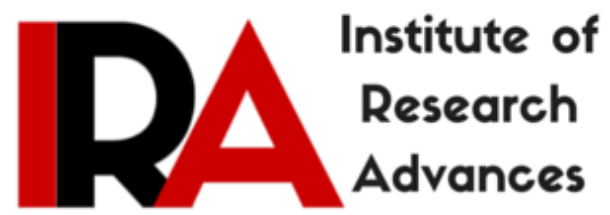

\title{
The Performance of Area, Production and Productivity of Pulses in Andhra Pradesh (With Reference to 13 Districts of Andhra Pradesh)
}

\author{
Srinivasa Rao Pasala ${ }^{1}$, Mahesh Rudra ${ }^{2}$ \\ ${ }^{1}$ Assistant Professor, Gayatri Vidya Praishad College for Degree and P.G. Courses (A), \\ Visakhapatnam, India. \\ ${ }^{2}$ Research Scholar, Department of Economics, Andhra University, India.
}

Type of Review: Peer Reviewed.

DOI: http://dx.doi.org/10.21013/jmss.v6.n1.p13

\section{How to cite this paper:}

Pasala, S., \& Rudra, M. (2017). The Performance of Area, Production and Productivity of Pulses in Andhra Pradesh (With Reference to 13 Districts of Andhra Pradesh). IRAInternational Journal of Management \& Social Sciences (ISSN 2455-2267), 6(1), $97-$ 103. doi:http://dx.doi.org/10.21013/jmss.v6.n1.p13

(C) Institute of Research Advances

(c) B EY-NC

This work is licensed under a Creative Commons Attribution-Non Commercial 4.0 International License subject to proper citation to the publication source of the work.

Disclaimer: The scholarly papers as reviewed and published by the Institute of Research Advances (IRA) are the views and opinions of their respective authors and are not the views or opinions of the IRA. The IRA disclaims of any harm or loss caused due to the published content to any party. 


\section{ABSTRACT}

Former Prime Minister Shri Lal Bahadur Shastri had given slogan of “ Jai Jawan, Jai Kisan”, Now the Prime Minister Shri Narendra Modi call to farmers to fill the granaries of nation, the farmers left no stone unturned to live up to his aspirations. He appeal each and every farmer, if they have five acre field, then use at least one acre land for cultivation of pulses and legumes so that India need not import it and pulses, which are basic source of protein are available to the poor at affordable price. In Andhra Pradesh (13 districts) the area under pulses is 13, 73,544 hectares in 2010-11 which accounted for 23.62 per cent in total food crops area, whereas the same in 2014-15 is 10,42,300 hectares which accounted for 20.03 per cent of total food crops area. Under the National Food Security Mission (NFSM) pulses being implemented in all the 13 districts of the state. An amount of Rs. 2378.04 lakhs was spent under NFSM- pulses up to 15-11-2015. An intensive analysis of data, the compound annual growth rates are very meager for area, production and productivity of pulses in Andhra Pradesh. The area, production and productivity growth rates of pulses are 0.0039, 0.026 and 0.022 respectively. The change in the growth rate of area was completely decelerated in all three periods (i.e. original, 3MA and 5MA). The same trend exhibits in production in original series. The main source of pulses growth due to yield. It is the time for the policy makers and government to concentrate on pulses production through spreading it to irrigated areas.

Key words: Compound Annual Growth Rate, Decomposition Analysis, Acceleration, Deceleration

\section{INTRODUCTION}

Mahatma Gandhi believed that India lives in villages and agriculture is the soul of Indian economy. These words still ring true today. Agriculture brings home the bread to nearly half of all households and supplies it to the remainder. It still provides large-scale employment opportunities and a major contributing factor for a labour-surplus economy like India. It also contributes significantly to the foreign trade of the country. Despite nature's command over agriculture, planned efforts may not be sufficient to keep up agriculture sector's contribution to the Indian economy and it is found to be disappointing always. Even though, India is the world's second biggest producer of rice and wheat. India is also a leading producer of pulses and oilseeds like soybean, groundnut and sunflower.

The contribution of agriculture and allied sectors to the Gross Value Added (GVA) (at 2011-12 series) of the country has been declining. The share of Agriculture and Allied Sectors in total GVA in 2011-12 is Rs. 15, 01,816 (percent to total GVA is 18.5), Rs. 16, 80,797 in 2012-13 (percent to total GVA is 18.2), Rs. 19, 02,452 in 2013-14 (percent to total GVA is 18.3) and Rs. 19, 95,251 in 2014-15(percent to total GVA is 17.4). Another side the percentage share of agriculture and allied sectors to the Gross Capital Formation (GCF) in 2012-13 is 8.6, in 2013-14 is 7.8, in 2014-15 is 8.6 and in 2015-16 is 7.7. Further, while the annual rate of growth of agriculture was 3.1 percent in the overall GDP growth of 3.9 percent during 1951 - 61, it has hit a plateau of 1.5 percent in 2012-13 while the overall growth being about 5.4 percent, The annual growth of agriculture in 2013-14 was 4.2 percent while the overall GVA being about 6.3 percent and -0.2 percent and 7.1 percent for agricultural and allied sectors and GVA respectively in 2014-15. The estimated annual growth of agriculture is 1.14 percent while the overall GVA is estimated at 7.6 percent during 2015-16.

Former Prime Minister Shri Lal Bahadur Shastri had given slogan of “ Jai Jawan, Jai Kisan”, Now the Prime Minister Shri Narendra Modi call to farmers to fill the granaries of nation, the farmers left no stone unturned to live up to his aspirations. He appeal each and every farmer, if they have five acre field, then use at least one acre land for cultivation of pulses and legumes so that India need not import it and pulses, which are basic source of protein are available to the poor at affordable price. 


\section{Performance of Pulses in Indian Agriculture - A brief account}

Agriculture plays a vital role in the Indian economy both in terms of providing employment and contribution to Gross Domestic Product. Indian agriculture has shown an impressive growth over the last few decades despite weather and price shocks. It has registered a remarkable growth in terms of output. India has the distinction of being the first in the world in the production of maize, pulses and jute, second in rice, wheat, sugarcane, vegetables and fruits.

Pulses occupy an important place in Indian agriculture. In India, pulses are grown over an area of 2.38 crore hectares with the total production of 1.86 crore tones. The average yield of pulses in India about $735 \mathrm{Kg}$ / hectare. The country need to produce 40-50 lahk tones of additional pulses for meeting the domestic requirement and it is clear that the production pattern for pulses is change from old face to new fate i.e. develop high yields varieties in addition that most of the land dedicated to growing pulses in each state un-irrigated as well as irrigated land, but the national output of pulses comes predominantly from un-irrigated land. In contrast, a large share of output in wheat, rice and sugarcane - in Punjab, Haryana and UP - is from irrigated land. In water scarce Maharashtra, all sugarcane is grown on irrigated land. Meeting the high and growing demand for pulses in the country will require large increases in pulses production on irrigated land, but this will not occur if agriculture policies continue to focus largely on cereals and sugarcane.

\section{Performance of Pulses in Andhra Pradesh Agriculture - A brief account}

The major pulses producing states in India are Madhya Pradesh, Maharashtra, Rajasthan, Uttar Pradesh, Andhra Pradesh and Karnataka. These six states account for 79 percent of area and 80 percent of production of pulses in India. These pulses crops can be grown in kharif and rabi seasons in India and cultivated in marginal lands under rainfed conditions. Only 15 percent of area under pulses has assured irrigation. Among these six major pulses producing states in India, the productivity per hectare vary significantly from one state to another state. In Andhra Pradesh (13 districts) the area under pulses is 13, 73,544 hectares in 2010-11 which accounted for 23.62 per cent in total food crops area, whereas the same in 2014-15 is 10,42,300 hectares which accounted for 20.03 per cent of total food crops area. Under the National Food Security Mission (NFSM) pulses being implemented in all the 13 districts of the state. An amount of Rs. 2378.04 lakhs was spent under NFSM- pulses up to 15-11-2015.

\section{Brief Literature Review}

Virendra Kumar (2016), article stated that Cultivation of pulse crop is must once in a year for every farmer for maintaining soil fertility, betterment of soil fertility, betterment of their livelihood, increased farm income and enhancing the nutritional security. After harvest of sorghum, barley, wheat and maize farmers should grow gram, red gram, green gram and lentil. There is need for increasing production of pulses as per capita availability of pulses is only $37 \mathrm{~g} /$ day as against $54 \mathrm{~g} / \mathrm{day}$ required to fulfill the protein requirement. Under the changing climatic scenario, more emphasis shall be given to achieving the target of 2.4 crore tones of pulses production by 2020 so as to make self sufficiency and reduce the burden of import bill substantially. For reaching the self sufficiency he suggested that pulse crops should be grown along with food and cash crops in the cropping sequence. Small and marginal farmers can also increase soil fertility of their farm land by growing short duration pulse crops and applying crop residue in the soil.

Breeding effort needs to be directed towards development of climate resilient, short duration (5055 days), high yielding, yellow vein mosaic virus resistant moong bean varieties for cultivation as a cash crop in a short window of rice-wheat cropping system. Similarly, early maturing (100 days) lentil, chickpea and pigeon pea (110-120 days) would increase production and fetch additional income to the farmers .Durgesh et. al., (2016), paper stressed that there is an urgent need to make the quality seeds available to the farmers at right time and places. Village level seed production unit will give great drive to this. 


\section{Need for the Study}

Pulses are usually cultivated as mixed crops such as cotton, mustard, or cash crops between two cereal crops. Long duration of crops, susceptibility to pest and diseases, low yield as compared to other grains etc. are some of the reason that the pulses have not been preferred crop for farmers. This has resulted in India's dependency on imports of pulses there by leading to increase in price of pulses. Realizing grimness of the situation, Prime Minister Shri. Narendra Modi recently urged the farmers to grow more and more pulses. For boost up the pulses production, the government of India has taken several steps to increase pulses production and to incentivize pulses growing farmers including announcement of minimum support price (MSP) for pulses for the first time. Further to boost up the pulses production, all 638 districts of 30 states have been included in the National Food Security Mission. Under NFSM, financial assistance is given for various interventions like demonstration of improved technology, distribution of quality seeds of new varieties, integrated pest management, water saving devices and capacity building of farmers. For expansion of cultivation of new kinds of seeds, Rs. 7.85 lakh mini-kits are being distributed to farmers free of cost in the year 2016-17, through state governments. Even then the government of Andhra Pradesh could not reach a significant growth in pulses production. In this context, it is necessary to know the true picture of pulses production in Andhra Pradesh.

\section{Objectives of the Study}

The major objectives of the study are

1. To analyse the trends in growth of area, production and productivity of pulses in Andhra Pradesh

2. To analyse the growth of area, production and productivity is accelerated or decelerated in Andhra Pradesh.

3. To examine the sources of growth of production of pulses in Andhra Pradesh.

\section{Data Sources and Methodology of the study}

As the present study focuses on the secondary data during the 1991-92 to 2014-15 in order to examine the growth rate of area, production and productivity of pulses was estimated by employing loglog regression model and further to test acceleration or deceleration of growth trends of area, production and productivity of pulses was used. Additive decomposition model is employed to identify the major factors that enhance the growth of pulses in Andhra Pradesh.

\section{Methods, Results and Discussions}

\section{A). Regression Growth Trend of Pulses}

To verify the importance and growth of sector, an exercise had been made to estimate the growth trend of area, production and productivity of pulses. To estimate this, log-log regression model was employed, and for which, a time series data from 1992-93 to 2014-15 was gathered. The regression growth equation with respect to time can be written as:

$$
\operatorname{Ln} Y_{t}=a+b t
$$

Where, Ln= Natural $\log ; \mathrm{Y}=$ Area or Production or Productivity of pulses; $\mathrm{a}=$ Constant; $\mathrm{b}=$ Coefficient and $\mathrm{t}=$ Time variable.

This model was estimated by employing original series (the entire period from 1991-92 to 201415), the three year's (3-period) moving average ( $3 \mathrm{MA}$ ) and five year's (5-period) moving average (5 MA) for all three variables- area, production and productivity of pulses in Andhra Pradesh. 
Table.1

Growth Rates of Area, Production and Productivity of Pulses in Andhra Pradesh

\begin{tabular}{|c|c|c|c|c|}
\hline \multirow{2}{*}{ source } & Series & Estimate of $b$ & Adjusted $\mathrm{R}^{2}$ & CAGR \\
\hline & \multicolumn{3}{|c|}{$\ln Y=a+b t$} & \\
\hline \multirow{6}{*}{ Area } & Original & 0.014 & 0.446 & 0.0039 \\
\hline & & $(4.415)^{*}$ & & \\
\hline & $3 \mathrm{M} \mathrm{A}$ & 0.017 & 0.702 & 0.0093 \\
\hline & & $(7.104)^{*}$ & & \\
\hline & $5 \mathrm{M} \mathrm{A}$ & 0.018 & 0.808 & 0.01176 \\
\hline & & $(8.994)^{*}$ & & \\
\hline \multirow{6}{*}{ Production } & Original & 0.043 & 0.698 & 0.026 \\
\hline & & $(7.363)^{*}$ & & \\
\hline & $3 \mathrm{M} \mathrm{A}$ & 0.047 & 0.838 & 0.0339 \\
\hline & & $(10.466)^{*}$ & & \\
\hline & $5 \mathrm{M} \mathrm{A}$ & 0.049 & 0.867 & 0.033 \\
\hline & & $(11.169)^{*}$ & & \\
\hline \multirow{6}{*}{ Yield } & Original & 0.029 & 0.647 & 0.022 \\
\hline & & $(6.568)^{*}$ & & \\
\hline & $3 \mathrm{M} \mathrm{A}$ & 0.03 & 0.851 & 0.0247 \\
\hline & & $(10.999)^{*}$ & & \\
\hline & $5 \mathrm{M} \mathrm{A}$ & 0.031 & 0.891 & 0.0216 \\
\hline & & $(12.495)^{*}$ & & \\
\hline
\end{tabular}

* One percent level of significance; CAGR-Compound Annual Growth Rate

Note: Values in the parenthesis represent $t$-values

As shown in the Table.1, in all three series - original, three year (3 MA) and five year moving average (5 MA) for area, production and yield, the estimates of $b$ i.e. the coefficient of the time variable $t$, was found to be a statistically significant at 1 percent probability level. As determined by the adjusted $\mathrm{R}^{2}$ value, growth rate of production was found to be the highest at 0.03 percent in twenty four years, followed by yield with 0.02 per cent. The growth rate of area was at the lowest with 1 percent probability level for all three data series compared to production and productivity, as determined by the adjusted $\mathrm{R}^{2}$ values.

\section{B). Growth Trend Estimates through Quadratic Equation}

To identify further whether the growth rate of three variables - area, production and productivity has been accelerating or decelerating, a quadratic equation was also used. It is arrived at by comparing the level of statistical significance and the value of estimates of $c$ of equation (2) over the b of equation (1). The equation is given as:

$\log Y_{t}=a+b t+c t^{2}$

Where, $\mathrm{c}=$ Coefficient of $\mathrm{t}^{2}$ 
Table.2.

Change in Growth Rates of Area, Production and Productivity

${ }^{*}$ indicates 1 percent level of significance, ${ }^{* *}$ indicates 5 percent level of significance, ${ }^{* * *} 10$ percent level of significance;CAGR-Compound Annual growth Rate; Note: Values in the parenthesis indicates the t-values

\begin{tabular}{|c|c|c|c|c|c|}
\hline & Series & Estimate of $b$ & Estimate of $c$ & Adjusted $\mathbf{R}^{2}$ & Remark \\
\hline & & \multicolumn{4}{|c|}{$\ln Y=a+b t+c t^{2}$} \\
\hline \multirow{6}{*}{ Area } & \multirow[t]{2}{*}{ Original } & 0.042 & -0.004 & \multirow[t]{2}{*}{0.543} & \multirow[t]{2}{*}{ Decelerating } \\
\hline & & $(3.479)^{*}$ & $(-2.383)^{* * *}$ & & \\
\hline & \multirow{2}{*}{$3 \mathbf{M A}$} & 0.042 & -0.001 & \multirow[t]{2}{*}{0.776} & \multirow[t]{2}{*}{ Decelerating } \\
\hline & & $(4.506)^{*}$ & $(-2.765)^{*}$ & & \\
\hline & \multirow[t]{2}{*}{$5 \mathbf{M A}$} & 0.046 & -0.001 & \multirow[t]{2}{*}{0.886} & \multirow[t]{2}{*}{ Decelerating } \\
\hline & & $(5.913)^{*}$ & $(-3.64)^{*}$ & & \\
\hline \multirow{6}{*}{ Production } & \multirow{2}{*}{ Original } & 0.077 & -0.001 & \multirow[t]{2}{*}{0.714} & \multirow[t]{2}{*}{ Neither accelerate nor decelerate } \\
\hline & & $(3.264)^{*}$ & $(-1.494)$ & & \\
\hline & \multirow[t]{2}{*}{$3 \mathbf{M A}$} & 0.095 & -0.002 & \multirow[t]{2}{*}{0.88} & \multirow[t]{2}{*}{ Decelerating } \\
\hline & & $(5.445)^{*}$ & $(-2.83)^{*}$ & & \\
\hline & \multirow{2}{*}{$5 \mathrm{MA}$} & 0.11 & -0.02 & \multirow[t]{2}{*}{0.923} & \multirow[t]{2}{*}{ Neither accelerate nor decelerate } \\
\hline & & $(6.643)^{*}$ & $(-3.762)$ & & \\
\hline \multirow{6}{*}{ Yield } & \multirow[t]{2}{*}{ Original } & 0.035 & 0.000 & \multirow[t]{2}{*}{0.632} & \multirow[t]{2}{*}{ Neither accelerate nor decelerate } \\
\hline & & $(1.884)^{* * *}$ & $(-0.351)$ & & \\
\hline & \multirow[t]{2}{*}{$3 \mathbf{M A}$} & 0.052 & -0.001 & \multirow[t]{2}{*}{0.868} & \multirow[t]{2}{*}{ Neither accelerate nor decelerate } \\
\hline & & $(4.419)^{*}$ & $(-1.887)$ & & \\
\hline & \multirow[t]{2}{*}{$5 \mathrm{MA}$} & 0.062 & -0.001 & \multirow[t]{2}{*}{0.924} & \multirow[t]{2}{*}{ Neither accelerate nor decelerate } \\
\hline & & $(5.912)^{*}$ & $(-2.963)$ & & \\
\hline
\end{tabular}

As shown in the Table.1, the growth rates in original, $3 \mathrm{MA}, 5 \mathrm{MA}$, as per adjusted $\mathrm{R}^{2}$ area were $0.003,0.009$ and 0.011 respectively and found statistically significant. However, in Table.2, area was found to be statistically significant and found to be decelerating trend in original, $3 \mathrm{MA}$ and $5 \mathrm{MA}$ series. The growth rate of production is statistically significant with accelerating trend in 3 MA data series. The growth rate of production under pulses in Andhra Pradesh is expected to be neither accelerate nor decelerate in original and $5 \mathrm{MA}$ series data. The growth rate in productivity/ yield under pulses in the state is expected to be neither accelerate nor decelerate in original, $3 \mathrm{MA}$ and $5 \mathrm{MA}$ series data. 


\section{C). Effects of Pulses growth Trend in Andhra Pradesh}

So far we understood the growth trends of area, production and productivity of pulses in State. The present section focuses on the decomposition on the growth of area and productivity to identify the effects that contribute to the growth of output of pulses in Andhra Pradesh. The following model was used, based on the growth trend determined above.
$\mathrm{Q}_{\mathrm{t}}=\mathrm{A}_{\mathrm{t}} * \mathrm{Y}_{\mathrm{t}}$
Where $Q_{t}=$ Output at time $t$
$\mathrm{A}_{\mathrm{t}}=$ Area at time $\mathrm{t}$
$\mathrm{Y}_{\mathrm{t}}=$ Productivity at time $\mathrm{t}$
Further, the decomposition model can be estimated by additive model given by
$\mathrm{Q}_{\mathrm{t}}-\mathrm{Q}_{0}=\left(\mathrm{A}_{\mathrm{t}}-\mathrm{A}_{0}\right) \mathrm{Y}_{0}+\left[\left(\mathrm{Q}_{\mathrm{t}}-\mathrm{Q}_{0}\right)-\left(\mathrm{A}_{\mathrm{t}}-\mathrm{A}_{0}\right) \mathrm{Y}_{0}\right]$
Where $\left[\left(Q_{t}-Q_{0}\right)-\left(A_{t}-A_{0}\right) Y_{0}\right]=$ Productivity effect
$\left(A_{t}-A_{0}\right) Y_{0}=$ Area Effect
Table 3
Decomposition for Pulses Output in Andhra Pradesh

\begin{tabular}{lcccc}
\hline \multicolumn{5}{c}{ Additive Model } \\
\hline Series & Area Effect & Yield Effect & Interaction Effect & Total \\
\hline Original & -0.086 & 1.092 & -0.006 & 1.000 \\
3 M A & 0.192 & 0.827 & -0.019 & 1.000 \\
5 M A & 0.312 & 0.667 & 0.021 & 1.000 \\
\hline
\end{tabular}

From the Table.3, we can infer that the shares of area expansion and yield improvement on the total increase in output of pulses are expressed in absolute figures. This gives the area and productivity effect respectively, and addition of the two makes one (gives in last column of Table.3.). The area productivity effect was observed to be highly influential the growth of pulses output, found more visible in the original series (1.092 percent). The area effect was found to be negative in the original series data and relatively lower in $3 \mathrm{MA}$ and $5 \mathrm{MA}$ series data. This implies that the growth rate of pulses was mainly enthused by productivity effect and the area effect was found to be negative and less stagnant during the study period. This might be probably to crop shift.

\section{Conclusions}

From the intensive analysis of data, the compound annual growth rates are very meager for area, production and productivity of pulses in Andhra Pradesh. The area, production and productivity growth rates of pulses are $0.0039,0.026$ and 0.022 respectively. The change in the growth rate of area was completely decelerated in all three periods (i.e. original, 3MA and 5MA). The same trend exhibits in production in original series. The main source of pulses growth due to yield. It is the time for the policy makers and government to concentrate on pulses production through spreading it to irrigated areas.

\section{References}

1. Verendra Kumar (2016), "Role of Pulses in Indian Agriculture", Kurukshetra (A Journal of Rural Development), November, 2016, Vol.No.65, No.1, pp.10-15.

2. Kumar durgesh, Rehka Joshi and A Talukdar (2016), "Sustaining Pulses Productivity In India Through Technological And Policies Interventions", Kurukshetra (A Journal of Rural Development) November, 2016, Vol.No.65, No.1, pp.28-32.

3. Srivastava, S.K., Sivaramane, N., Mathur, V.C. (2010), "Diagnosis of Pulses Performance of India", Agricultural Economics Research Review, 23 (1):137-148

4. Indian Economic Survey, 2016.

5. Anadhra Pradesh Economic Survey-2016 and various Andhra Pradesh Statistical Abstracts, Government of Andhra Pradesh. 